\title{
Wyobraźnia twórcza - o źródłach teoretyzowania w nauce o polityce
}

\section{Creative Imagination - the Source of Theorizing in Political Science}

\begin{abstract}
The aim of this paper is to analyze the phenomenon of creative imagination as source the creation theory and scientific theorizing in political science. In this understanding, the author made three-views of key topics methodological reflection, which are synonymous the mechanism of the scientific theorizing in political science. The three-views proceed as follows: human imagination $\rightarrow$ indirectness of scientific cognition $\rightarrow$ creative theorizing.
\end{abstract}

Keywords: creative imagination, illumination, creative theorizing, directness/indirectness of scientific cognition, divergent thinking

Tworzenie teorii w praktyce naukowej - rozumianych jako spójny, uporządkowany oraz uzasadniony według wcześniej ustalonych kryteriów system twierdzeń o rzeczywistości - jest nieodłącznym elementem procesu badawczego. $\mathrm{W}$ tym ujęciu teorie można rozpatrywać $\mathrm{z}$ jednej strony jako zabieg poznawczo-wyjaśniający będący synonimem zaawansowanych dociekań w obrębie wyznaczonego obszaru wiedzy, z drugiej zaś jako spersonalizowany element twórczości - naukowej heurystyki. W pierwszym wypadku teorie, oprócz faktów i praw naukowych, współtworzą intersubiektywną i czasowo obowiązującą wiedzę tła w sformalizowanej dyscyplinie nauki, gdzie dopuszcza się dobrowolność dochodzenia do danych tez i naukowych twierdzeń o świecie, lecz jednocześnie przywiązuje się szczególną wagę do kryteriów uzasadniania tychże twierdzeń (Such, 1975, s. 7-35). Ściślej rzecz ujmując, chodzi o uzyskanie przez wysuwane hipotezy bądź orzekane sądy o danym przedmiocie badań rangi twierdzeń naukowych (mechanizm asercji twierdzeń naukowych) ${ }^{1}$. W drugim wypadku mowa o stop-

Zdaniem Kazimierz Ajdukiewicza uzasadnienie odgrywa centralną rolę w praktyce naukowo-badawczej. Stąd, pamiętając o podstawowym rozróżnieniu na nauki dedukcyjne i indukcyjne, 
niowalnym uczestnictwie podmiotu w samym procesie badawczym, gdzie ludzka aktywność umysłowa - szczególnie percepcja pośrednia, intuicja, spontaniczne asocjacje, twórcze myślenie - staje się ważną przesłanką do formułowania naukowych sądów o rzeczywistości. Jak słusznie podkreślił Stefan Nowak - to moment zauważenia trudności wyraźnego rozgraniczenia w refleksji naukowej „bezpośredniej obserwowalności” (bezpośredni sąd spostrzeżeniowy) od „inferowalności" (pośrednio-intelektualne wnioskowanie z sądu spostrzeżeniowego), która warunkowana jest podmiotem badającym (2007, s. 396)².

W takich okolicznościach nasuwają się następujące pytania badawcze: Czy źródeł tworzenia teorii w nauce o polityce można i należy poszukiwać w wyobraźni teoretyków? W jakim stopniu pojęcia teoretyczne - szerzej teorie naukowe - opierają się na bezpośredniości poznania (obserwacji), a w jakim odnoszą się do badaczy, ich płaszczyzny psychiczno-przeżyciowej czy introspekcyjnej? Czy w politologicznej pracy naukowej jest miejsce na wyobraźnię?

Chcąc precyzyjnie odpowiedzieć na te pytania, dokonano trójstopniowej odsłony głównych wątków refleksji metodologicznej, które związane są z mechanizmem tworzenia teorii naukowych. Odsłona będzie przebiegać według schematu: wyobraźnia ludzka $\rightarrow$ pośredniość poznania $\rightarrow$ twórcze teoretyzowanie.

\section{Źródła sporu o wyobraźnię w nauce}

Punktem wyjścia eksplikacji pojęcia wyobraźni - w tym wyobraźni twórczej w praktyce naukowo-badawczej jest teza o autonomii kontekstu odkrycia i uzasadniania ${ }^{3}$, będąca przedmiotem wielu kontrowersji na gruncie metodologii nauki. Ta intelektualna polemika wskazuje na dwie antagonistyczne postawy poznawcze w kontekście różnic i/lub ich braku między wiedzą potoczną a naukową, tj. kontynualizm i dyskontynualizm. Pierwsze stanowisko postuluje płynne przejście od wiedzy potocznej do naukowej, gdzie nie widzi się istotnych różnic w przedmiocie tych dwóch rodzajów poznania (teza, że ostatecznym przedmiotem wszelkiego poznania jest zawsze rzeczywistość obiektywna), ich metodzie

można mówić o klasyfikatorycznym uzasadnieniu w naukach dedukcyjnych (twierdzenie jest naukowe, gdy jest uzasadnione, tzn. posiada dowód dedukcyjny) bądź komparatywnym uzasadnieniu w naukach indukcyjnych (hipoteza poddana weryfikacji zdobywa w oczach krytyki naukowej w miarę pomyślnego postępu tej procedury uprawnienie do coraz silniejszej asercji, tj. zasługuje na miano coraz lepiej uzasadnionej). Zob. Ajdukiewicz, 1985, s. 374-383.

2 W metodologii nauk empirycznych mowa o rozróżnieniu i/lub związkach między pojęciami elementarnymi (spostrzeżeniowymi) a pojęciami teoretycznymi. Zob. Przełęcki, 1966, s. 449-504. W polskiej politologii rozważania na temat kontekstu odkrycia i uzasadnienia m.in. w: Krauz-Mozer, 2005, s. 88-104; Krauz-Mozer, 2013, s. 45-56; Klementewicz, 2004, s. 234-260. 
(ograniczenie badania do poziomu podstawowego, tzn. sprowadzenie praktyki naukowej i refleksji potocznej do elementarnych mechanizmów myślenia - np. analiza-synteza, asymilacja-akomodacja - bądź do elementarnych operacji poznawczych - np. obserwacji czy uogólnienia), jak też języku (teza, że różnica języków jest tylko różnicą w środkach wyrazu, tj. nie dotyczy ani treści myśli, ani form przebiegu myśli). Natomiast dyskontynualizm odnosi się do zasadniczych odmienności i nieprzekraczalnej granicy między wiedzą potoczną a naukową, którą można sprowadzić do następujących różnic: bezpośredniość przedmiotu poznania (rozumowanie potoczne jest ustawione od rzeczy do umysłu. Z kolei rozumowanie naukowe od umysłu do przedmiotowych - techniczno-eksperymentalnych - wcieleń umysłu, wcieleń tworzonych przez umysł struktur pojęciowych); płaszczyzna myślenia (myślenie naukowe, w przeciwieństwie do potocznego, z zasady opiera się na schematach inferencyjnych); płaszczyzna językowa (w tym sensie język nauki jest bardziej sformalizowany, zakresowy, ostry czy niewieloznaczny) (Cackowski, 1979, s. 27-42).

Niewątpliwie obie orientacje epistemologiczne rzutują na praktykę naukową - ściślej na zaliczenie danych sądów o rzeczywistości do zbioru twierdzeń określonej teorii - i ich powiązanie $\mathrm{z}$ wyobraźnią podmiotu badającego. Innymi słowy, powstaje kontrowersja na temat analizowania mechanizmu teoretyzowania i tworzenia teorii na gruncie nauki o polityce. $Z$ jednej strony mowa o pełnej niezależności kontekstu odkrycia i kontekstu uzasadnienia, gdzie naukowe procesy epistemiczne związane $\mathrm{z}$ powstawaniem teorii są autonomiczne względem procedur odnoszących się do ich weryfikacji i/lub falsyfikacji. Oznacza to, że „naukowym” nazwiemy takie twierdzenie, które według wcześniej ustalonych kryteriów zostało zadowalająco (w odpowiednim stopniu) uzasadnione i potwierdzone przez określoną wspólnotę badaczy. W tym rozumieniu wtórny - nie tak znaczący - okazuje się sam proces badawczy, etapy dochodzenia do końcowych wniosków, w tym związane z nimi konceptualizacja i operacjonalizacja schematu badania, za to najistotniejsze jest uargumentowanie wyników, potwierdzające lub zaprzeczające uzasadnienie wysuwanych hipotez czy wreszcie prawdziwość/fałszywość orzekanych sądów, twierdzeń lub prognoz. Z drugiej zaś strony mowa o wzajemnym przenikaniu się obu kontekstów, co w tym akurat wypadku dowartościowuje kontekst odkrycia. To moment, w którym nie zapomina się, że najważniejszym ogniwem procesu badawczego jest zawsze podmiot $\mathrm{w}$ całokształcie swych cech ( $\mathrm{w}$ naukoznawstwie to synonim prowadzenia intensywnych badań z zakresu psychologii twórczości) (Maruszewski, 1983, s. 151 i n.). Taki wniosek otwiera możliwości badań nad związkami wyobraźni - zwłaszcza twórczej pracy naukowej - z mierzalnymi rezultatami tejże pracy, tj. m.in. z powstającymi teoriami naukowymi. Mowa o specyficznych zdolnościach ludzi nauki prowadzących do generowania pomysłów (Kozielecki, 1968, 
s. 24), na których zasadzają się dane rozwiązania teoretyczne. Stwarza to realne możliwości urzeczywistnienia się oryginalnej i doniosłej poznawczo wiedzy naukowej, zwłaszcza powstania przełomowych praw czy nowatorskich teorii mających bezpośrednie przełożenie na jakościowy rozwój danej dyscypliny wiedzy, a w szczególnych wypadkach prowadzących do rewolucji naukowej i radykalnej zmiany paradygmatycznej w jej obrębie.

\section{Wyobraźnia twórcza}

Przed zdefiniowaniem pojęcia wyobraźni twórczej należy się odnieść do źródeł wyobraźni w kontekście zaistnienia danej aktywności umysłowej wśród ludzi. W psychologii poznawczej uaktywnienie się wyobraźni wiąże się z powstaniem wyobrażeń, szczególnie z mechanizmem fantazjowania i marzenia, które może być źródłem naukowej twórczości, w tym niepokoju twórczego, mającego z zasady przełamywać zastane schematy myślenia czy działania (Pieter, 1971, s. 43-47).

Wyobrażenie jest jedną z postaci poznawczej reprezentacji obiektu w umyśle. Charakteryzuje się brakiem trwałości oraz ścisłym powiązaniem z percepcją. Wyobraźnia to zdolność umysłu do generowania takich właśnie wyobrażeniowych reprezentacji świata. Tradycyjnie wyróżniono wyobraźnię odtwórczą i twórczą. Pierwsza miała być odpowiedzialna za tworzenie wyobrażeń obiektów wcześniej spostrzeganych i dobrze znanych [...]. Druga miała tworzyć konstrukcje fantazyjne lub „niemożliwe" [...]. Wyobraźnią twórczą nazywa się inną zdolność umożliwiającą tworzenie nie tylko nowych wyobrażeń, ale też nowych pojęć i innych reprezentacji poznawczych (Nęcka, Orzechowski, Szymura, 2013, s. 64) ${ }^{4}$.

Innymi słowy, wyobraźnia twórcza jest pewną zdolnością psychiczną jednostki związaną z szerokim i nietypowym kojarzeniem i przekształcaniem określonych informacji, danych, zmiennych, współczynników itd. w nowe jakości za

\footnotetext{
W psychologii poznawczej z pojęciem wyobraźni podmiotu badającego nieodłącznie łączy się kwestia powstawania reprezentacji umysłowych, gdzie próbuje się odpowiedzieć na pytanie, dzięki jakim strukturom świat jest odzwierciedlony i/lub reprezentowany w ludzkim umyśle. Stąd historyczny spór między realizmem (realny obiekt badań jest umysłowo reprezentowany tylko w sposób zgodny z formą i wyglądem ich realnych pierwowzorów) a konstruktywizmem (realny obiekt badań może być umysłowo reprezentowany na wiele różnych sposobów, zatem w zależności od nastawienia, doświadczenia, kontekstu, wiedzy, nastroju, emocji, motywacji itd. podmiotu badającego) (Nęcka, Orzechowski, Szymura, 2013, s. 64). Zob. również Maruszewski, 2011, s. 267-314.
} 
pomocą odpowiedniej wiedzy (wcześniej zdobyte oraz przetworzone informacje), właściwego poziomu motywacji, determinacji i zaangażowania emocjonalnego. Zgodnie z twierdzeniem:

Wyobraźnia twórcza, czynna, wytwórcza dotyczy wytwarzania nowych jakości. Wiąże się ją zazwyczaj z aktywnością jednostki, w wyniku której powstają nowe wartości i jakości. Jest ona zatem strukturalno-funkcjonalnym elementem zdolności twórczych człowieka. Część badaczy twierdzi wręcz, że wyobraźnia twórcza jest tym samym co zdolności twórcze [...]. W jednym przypadku wyobraźnię twórczą uważa się za właściwość związaną z szerokim i nietypowym kojarzeniem informacji, $w$ drugim natomiast z przekształceniami informacji. Kojarzenie i transformacje, według wielu badaczy, odbywają się przy wykorzystaniu analogii i metafory. Im odleglejsze są skojarzenia, tym bardziej twórcze jest to, co powstało w wyniku funkcjonowania wyobraźni twórczej (Limont, 1996, s. 29).

We współczesnej psychologii kognitywnej praktyczny wymiar wyobraźni sprowadza się do wspierania różnych procesów psychicznych - np. twórczości. W tym sensie wyobraźnia w procesie twórczym traktowana jest jako mechanizm kognitywny, ułatwiający wytwarzanie twórczych rozwiązań. Mowa o twórczej syntezie polegającej na łączeniu różnych informacji w oryginalny, niesztampowy sposób. To intelektualna rekonstrukcja danych percepcyjnych, która pozwala dostrzec nieoczywiste, ukryte atrybuty przedmiotu badania. Okazuje się, że w zależności od dziedziny twórczości można mówić o różnych typach wyobraźni. Wśród naukowców reprezentujących nauki ścisłe uwidocznia się wyobraźnia przestrzenna. Z kolei wśród przedstawicieli dyscyplin społecznych wyobraźnia „opisowa” (object imagery), która wiąże się z dużą szczegółowością samych wyobrażeń (Łukasik, 2008, s. 110-111)5. Przy czym twórczą wyobraźnię - $\mathrm{w}$ tym procesy wyobrażeniowe - należy utożsamiać z kreatywnością będącą nie tyle rozwiązaniem, ile ścieżką prowadzącą do danych rozwiązań. Stąd kreatywność w nauce to nie specyficzny produkt kreatywnych czynów (działalności) ludzi nauki, lecz raczej psychologiczna droga twórczej eksploracji, gdzie powstawanie nowych pomysłów czy koncepcji teoretycznych wiąże się m.in. z podmiotową intuicją; indywidualnymi możliwościami wykorzystania przez badaczy wcześniejszych koncepcji, modeli, siatek pojęciowych itd. w nie-

W psychologii kognitywnej podkreśla się, że procesy wyobrażeniowe: „przestają być procesami drugorzędnymi, wspierającymi jedynie intelektualne czynności człowieka, np. twórcze myślenie, integrują natomiast przynajmniej trzy podstawowe sfery umysłu: odbioru informacji (percepcji), przetwarzania informacji (myślenie), przechowywania/odtwarzania informacji (pamięć)”. W tym sensie spór odnośnie do tego, czym jest wyobraźnia, toczy się między przedstawicielami tzw. stanowiska obrazowego i stanowiska propozycjonalnego (Łukasik, 2008, s. 8 i n.). 
typowy sposób czy wreszcie ze specyficzną i oryginalną interpretacją otoczenia (przedmiot badania) (Finke, 1990, s. 168-172).

$\mathrm{Na}$ tym tle najistotniejszy wydaje się mechanizm konceptualnej ekspansji (conceptual expansion), definiowany jako podmiotowa możliwości poszerzenia istniejących struktur pojęciowych $w$ danej dziedzinie wiedzy i/lub proces luzowania (zmiany) granic danych pojęć czy kategorii, co jest szczególnie ważne $\mathrm{w}$ formułowaniu się nowych pomysłów czy urzeczywistnieniu się twórczego myślenia. W psychologii eksperymentalnej to synonim heurystycznej rekonstrukcji wyjściowych danych percepcyjnych w pracy naukowej, gdzie za pomocą kreatywnego myślenia próbuje się przezwyciężyć z jednej strony zastane schematy postrzegania czy interpretowania świata, z drugiej zaś w stopniowalny sposób zmienić obowiązującą wiedzę tła w danej społeczności uczonych (Ward, 1994, s. 1-40; Abraham, Windmann, Daum, Güntüurkün, 2005, s. 520-534).

Przykładem takiego luzowania granic danego pojęcia w języku politologicznym są współczesne zmiany, jakie zachodzą w wyznaczaniu desygnatów i zakresu konotacyjnego w stosunku do kategorii podmiotowości politycznej. Pod wpływem postępu naukowo-technicznego coraz wyraźniej akcentuje się mechanizm sprawstwa pozaludzkiego (non-human agency), gdzie $\mathrm{z}$ jednej strony uwidacznia się praktyczne zacieranie granic między aktywnością człowieka a rzeczywistą eksternalizacją rzeczy (zwłaszcza techniki/technologii), z drugiej zaś intensywnie analizuje się kulturę materialną jako podstawową determinantę polityki. To moment, kiedy rzeczy nie pozostają tylko jakimś drugoplanowym kontekstem ludzkich interakcji, ale stają się konstytutywnym nośnikiem działań i wartości; ucieleśnieniem podmiotowości; ważnym czynnikiem utrwalającym stosunki polityczne (Bińczyk, 2012, s. 181-213; Dant, 2007, s. 123-142; Carter, 2013, s. 36-45). W takich warunkach rzeczy - dokładniej różnego typu wytwory techniczne - są nowymi desygnatami podmiotowości, ponieważ stają się siłą sprawczą praktyki politycznej, a co ważniejsze ich aktywność oraz funkcjonowanie w przestrzeni społecznej powodują mierzalne skutki i obiektywizujące się następstwa o charakterze politycznym. Tego typu analizowanie materii polityki wymaga nie tylko wielowątkowej oraz interdyscyplinarnej wiedzy na temat relacji na styku człowiek $\leftrightarrow$ technika, lecz także heurystycznej rekonstrukcji danych percepcyjnych, gdzie teoretyk dzięki wyobraźni dokonuje konceptualnej ekspansji w politologicznej siatce pojęciowej.

Widać wyraźnie, że wyobraźnię można i należy łączyć z myśleniem twórczym $^{6}$. W tym sensie posługiwanie się wyobraźnią nie jest tylko prostą konty-

W psychologii mechanizm twórczości rozumiany jest na wiele sposób, m.in. jako: skutek/forma zaburzeń zachowania; konstruktywne rozwiązywanie problemów; pochodna bądź potrzeba człowieka do samorealizacji; asocjacyjne uczenie się i rozwiązywanie problemów. Zob. Żuk, 1986, s. 8 i n. 
nuacją postrzegania zmysłowego (percepcji bezpośredniej), lecz czymś więcej - dostrzeganiem nowych aspektów czy zaistnieniem zupełnie nowych asocjacji w toku pracy umysłowej. Stąd wyobraźnia staje się warunkiem koniecznym twórczości, gdzie podmiot analizujący rzeczywistość polityczną, uruchamiając wyobraźnie twórczą - interpretowaną jako zdolność do inwencji - dokonuje myślowego oglądu świata (Makota, 1988, s. 130). Innymi słowy, wyobraźnia może być, i często jest, źródłem intelektualno-koncepcyjnych zachowań człowieka. W niej powstają impulsy pobudzające umysł do ich konkretyzacji w postaci obrazów, idei czy określonego znaczenia. Wyobraźnia stanowi teren ujawniania się odczuć, przypuszczeń czy podświadomości.

Wyobraźnia jako źródło wszelkich transgresji pobudza inne dyspozycje i mechanizmy psychiczne do aktywności. Sama w sobie generuje zaledwie zarys pomysłu, praobraz, praideę, zaś inne mechanizmy ową praideę i praobraz ukonkretniają i oblekają w jakąś uświadomioną już formę bytu psychicznego. Wyobraźnia zatem najpierw generuje praideę, która zostaje jakby „poddana obróbce” przez inne mechanizmy psychiczne, a następnie już ową „obrobioną” praideę przedstawia jako ideę czy obraz. Pierwotnym generatorem idei i obrazów umysłowych jest wyobraźnia. Toteż wszelka twórczość ma swój początek w tej dyspozycji psychicznej. Zależność między tymi dwiema kategoriami jest, w moim przekonaniu, następująca: wyobraźnia staje na początku drogi zwanej procesem twórczym, na jej końcu jest konkretny wytwór w formie zobiektywizowanej (Górniewicz, 1995, s. 38).

Podsumowując dotychczasowe rozważania, można stwierdzić, że wyobraźnia jest związana ze zdolnością podmiotu do konceptualnej percepcji, gdzie bezpośredni ogląd czy obserwacja zastanej rzeczywistości może się stać katalizatorem twórczych poszukiwań czy powstania kreatywnych rozwiązań. Przy czym procesy wyobrażeniowe mogą również zaistnieć bez ekwiwalentu empirycznego, kiedy to uczony wyzwala w umyśle (świadomość introspekcyjna) różnego typu asocjacje, fantazje czy metafory służące do pracy twórczej. Takiej intelektualnej aktywności umysłowej towarzyszy najczęściej myślowa synteza będąca oznaką łączenia różnych problemów, odrębnych porządków, niezależnych czynników, wykluczających się płaszczyzn analizy itd. w jeden schemat myślowo-twórczy. Należy pamiętać, że uaktywnienie się wyobraźni jako istotnego elementu naukowego teoretyzowania warunkowane jest nie tylko aktywnością określonych obszarów mózgu uczonego, lecz także zależy od jego doświadczenia, poziomu wrażliwości, stopnia motywacji, predyspozycji psychofizycznych czy wreszcie okoliczności, w których pracuje (tworzy) i na temat których się wypowiada (orzeka). 


\section{Pośredniość poznania}

W takich warunkach proces naukowo-badawczy to wielopoziomowa i złożona relacja na styku podmiot $\leftrightarrow$ przedmiot badania, gdzie z punktu widzenia poznawczych źródeł tworzenia teorii naukowych mowa o wzajemnej koegzystencji uwarunkowań zewnętrznych (eksternalizm) i wewnętrznych (internalizm) (Morton, 2002, s. 172-175; Nagel, 1997, s. 111-134). To sprzężenie bezpośredniej obserwacji - ewidencji zmysłowej z pośredniością poznania - ludzkim doświadczeniem oraz interpretacją. Zgodnie z twierdzeniem Stefana Nowaka:

Tymczasem wiele terminów nauk społecznych jest tak definiowanych (lub też mają one taki sens, są tak pojmowane), iż bądź oznaczają wprost zjawiska ze sfery podległej bezpośredniej obserwacji i/lub doświadczenia wewnętrznego ludzi, bądź też poprzez mniej lub bardziej wydłużone łańcuchy zabiegów definicyjnych dają się one sprowadzić do jednego lub obu tych rodzajów doświadczenia. [...] W naukach społecznych obok obserwacji empirii doznań zmysłowych mamy również faktycznie dostępną badaczowi empirię jego własnych doznań introspekcyjnych oraz domniemaną przezeń na drodze rozumienia empirię doznań introspekcyjnych osób przez niego badanych. Tym ostatnim doznaniom przypisuje on własności i funkcje mniej lub bardziej podobne do tych, które zna $\mathrm{z}$ własnego doświadczenia wewnętrznego. [...] Terminy języka nauk społecznych mogą więc mieć odniesienie do dwóch rodzajów empirii znanych każdemu człowiekowi - empirii obserwacji zmysłowej i empirii doświadczenia wewnętrznego (Nowak, 2007, s. 82-83).

Przytoczona wypowiedź wpisuje się w zagadnienie genezy oraz uwarunkowań ludzkich systemów poznawczych, ściślej stanów intencjonalnych, mających treść spostrzeżeniową, wyobrażeniową, pojęciową czy propozycjonalną. $\mathrm{W}$ tym sensie uwypuklenie współzależności między płaszczyzną introspekcyjną podmiotu badającego a otoczeniem $\mathrm{w}$ praktyce naukowej jest zbieżne $\mathrm{z}$ eksternalizmem treści umysłowej. To stanowisko zakładające, że całościowe wyjaśnienie treści umysłowej podmiotu badającego wymaga uwzględnienia nie tylko czynników wewnętrznych (analiza internalistyczna, gdzie treść stanów umysłowych jest zdeterminowana przez infernalne, nierelacyjne własności podmiotu), lecz przede wszystkim czynników zewnętrznych względem tegoż podmiotu (analiza środowiska bezpośrednio oddziałującego na treści stanów mentalnych u ludzi). W tym rozumieniu treści ludzkich słów czy myśli - zwłaszcza twórcze myślenie i teoretyzowanie - nie zależą tylko i wyłącznie od mózgu (aktywności określonych obszarów w mózgu), lecz są warunkowane otoczeniem społeczno-kulturowym. Dlatego eksternalizm treści umysłowych zakłada, że: 
1. Do posiadania intencjonalnych stanów umysłowych (przekonań, wyobrażeń, poglądów itd.) konieczne jest funkcjonowanie w określonych relacjach strukturalno-społecznych (nie ma opinii, sądów czy światopoglądu o świecie bez tego świata).

2. Podmiot uprawiający naukę bez kultury i bez otoczenia byłby niezdolny do myślenia i realizowania naukowej referencji (nie ma myślenia i wnioskowania, w tym naukowej heurystyki, zwłaszcza tworzenia oryginalnych teorii, bez materialnych i niematerialnych wytworów kulturowych; bez kulturowo zakorzenionej aksjologii czy normatywności; bez sfery znaczeniowo-symbolicznej) (Poczobut, 2009, s. 373-385).

Mowa tu o łączeniu świadomości percepcyjnej $\mathrm{z}$ introspekcyjną $\mathrm{w}$ trakcie badania, gdzie z jednej strony mamy do czynienia z subiektywnie nakierowaną percepcją podmiotu na obszar dociekań, $\mathrm{z}$ drugiej zaś $\mathrm{z}$ refleksyjnie korygowaną informacją empiryczną, która staje się synonimem mechanizmu uspołecznienia określonych treści empirycznych. W praktyce naukowej takie uspołecznienie wiąże się z wypracowaniem, akceptacją oraz stosowaniem określonych standardów, procedur, dyrektyw itd. w danej wspólnocie badaczy. W tym ujęciu powstanie twórczych teorii naukowych za pomocą wyobraźni warunkowane jest dwoma pozostającymi $w$ ścisłej zależności komponentami, tj. podmiotowym i środowiskowym (Pierzchalski, 2014, s. 295-313).

Warto zauważyć, że wyjaśnienie mechanizmu tworzenia teorii w nauce o polityce jako procesu dynamicznej współzależności komponentu podmiotowego ze środowiskowym jest ściśle związane z problemem odzwierciedlenia myśli zwłaszcza introspekcyjnej zdolności podmiotu odnoszenia się do myśli, tj. myślenia o myślach - w danym języku naturalnym. Wśród wielu konkurencyjnych teorii i podejść badawczych odnośnie do relacji myśli-język najistotniejsze wydaje się ukazanie języka jako nośnika, przez który strukturalizują się myśli, a co ważniejsze - istnieje możliwość zaistnienia wyobraźni „opisowej” w procesie badawczym tak charakterystycznej dla nauk społecznych. Chodzi o uchwycenie formowania się myśli w zdania/sądy o świecie, które nie tylko wiążą się ze spostrzeżeniem zmysłowym teoretyka, ale także oznaczają mechanizm językowego dopasowania do reprezentowania obiektów (przedmiotów analizy) w danym języku naturalnym przez badacza, co współtworzy jego świadomość introspekcyjną i/lub samowiedzę. Innymi słowy, teoretyzowanie w nauce o polityce za pomocą wypowiedzianych bądź spisanych sądów o świecie jest nieodłącznie związane z umysłem podmiotu badającego, którego wewnętrzne myśli bądź wyobrażenia są ściśle połączone z używanym językiem naturalnym ${ }^{7}$. Zgodnie z tezą José Luisa Bermúdeza:

Wśród uczonych podnoszących problem relacji między językiem a myślą istnieje spór odnośnie do powstawania wyobrażeń w naszym umyśle. Kwestią sporną pozostaje nadal włączenie 
Nie jesteśmy nigdy świadomi propozycjonalnych myśli, które nie mają nośników językowych. Kiedy jesteśmy świadomi myśli propozycjonalnych, jesteśmy świadomi zobrazowanych zdań. Tym, co poddajemy introspekcji, kiedy poddajemy introspekcji nasze myśli propozycjonalne w sposób wymagany dla procesów dynamiki kognitywnej drugiego rzędu [zdolność myślenia o myślach - przyp. F.P.], jest mowa wewnętrzna (Bermúdez, 2003, s. 160).

W takich warunkach zarówno wyartykułowana w postaci zdań i sądów podmiotowa wiedza propozycjonalna, jak i publiczny język komunikacji w obrębie danej społeczności uczonych zależą od języka naturalnego, którym się posługują; od obowiązującego oraz konwencjonalnego słownika $S$ wyrazów $W$ w sformalizowanej dyscyplinie wiedzy; od siatek pojęciowych, kategorii, definicji, nazw itd., które posiadają określoną ekstensję/intencję, i które są przedmiotem dyskusji wśród kompetentnych badaczy-teoretyków ${ }^{8}$. Jednocześnie jednym z elementów językowej praktyki naukowej jest tzw. mowa wewnętrzna, w skład której wchodzi językowo umotywowana wyobraźnia - w tym immanentne wyobrażenia, fantazje czy olśnienia - która w stopniowalny sposób warunkuje introspekcyjny charakter każdego poznania naukowego.

\section{Twórcze teoretyzowanie}

Uaktywnienie się procesów wyobrażeniowych w kontekście prowadzenia rozważań teoretycznych oznacza, że wyobraźnia jest traktowana jako ważne narzędzie myślenia, które werbalizuje się co najmniej na dwa sposoby:

1. W postaci twórczych - wcześniej niezdiagnozowanych, analizowanych i wyjaśnianych - pomysłów, idei, asocjacji, koncepcji, rozwiązań itd., znajdujących zastosowanie w danym sformalizowanym systemie teoretycznym.

2. W postaci odtwórczych - wcześniej zdiagnozowanych, analizowanych i wyjaśnianych - pomysłów, koncepcji, rozwiązań, modeli itd., które zostają na nowo zinterpretowane, opracowane, wyjaśnione oraz ponownie sformalizowane w postaci teorii naukowej.

$\mathrm{W}$ obu wypadkach mamy do czynienia $\mathrm{z}$ rozwojem teoretycznym w obrębie danej dyscypliny wiedzy, kiedy to wyobraźnia staje się przesłanką wyjściową do podjęcia refleksji naukowej. Dla twórczego teoretyzowania oznacza to podjęcie

zewnętrznego systemu reprezentacji (języka) do opisu procesów poznawczych i traktowania tegoż systemu jako nośnika umożliwiającego zaistnienie tzw. wewnętrznych reprezentacji (myśli, wyobrażenia) (Gut, 2009, s. 329-385). Zob. Żukrowska, 2002.

8 Więcej na ten temat zob. Pierzchalski, 2013a, s. 245-267. 
zupełnie nowych wątków, problemów badawczych (zwłaszcza w sensie przedmiotowym i zakresowym), płaszczyzn analizy itd. przez badacza, kiedy to uczony stara się wyjść poza utarte schematy myślenia czy badania. Oznacza to moment mentalnego „zawieszenia” przez podmiot obowiązującej bazy pojęciowej, teoretycznej i metodologicznej, będącej źródłem jego samowiedzy. Celem jest poszukiwanie twórczych, niestandardowych rozwiązań czy koncepcji, gdzie obowiązujące aksjomaty, sformalizowane procedury, usystematyzowane reguły czy dyrektywy stają się w jakiejś mierze intelektualną przeszkodą w pracy naukowej. Takie mentalne "zawieszenie" może przebiegać w różny sposób i wynikać zarówno z podmiotu badającego (poziomu jego motywacji, nastawienia, poglądów, stopnia zaangażowania i chęci rozwikłania trudności, anomalii czy problemu), jak również przedmiotu badania, tzn. uwarunkowań zewnętrznych (w tym ograniczeń epistemicznych, braku dostępu do informacji czy instrumentarium techniczno-metodologicznego), w których prowadzona jest analiza teoretyczna. Dodatkowo można zaobserwować co najmniej jedną prawidłowość opartą na mentalnym „zawieszeniu”, która sprzyja twórczym rozwiązaniom teoretycznym w obrębie nauki o polityce. Mowa o przedmiotowej interdyscyplinarnej strategii syntetyzującej, gdzie w analityczny sposób definiuje się nowy przedmiot badania ze złożonego i temporalnego zbioru, jakim jest przestrzeń polityczna. W ten sposób łączy się w analizie oraz narracji politologicznej różne wątki, czynniki, płaszczyzny, argumenty, pojęcia itd. w jeden spójny system sądów teoretycznych. W tym układzie kreacja z wyobraźnią polega na poszukiwaniu nowego obszaru badań i twórczej syntezie myślowej, gdzie dokonuje się niestandardowej, heurystycznej argumentacji, która wcześniej była zarezerwowana dla odrębnych dyscyplin wiedzy.

Przykładem tego typu teoretyzowania mogą być chociażby interdyscyplinarne badania nad fenomenem kompleksowości w przestrzeni politycznej, kiedy to definiuje się zupełnie nowy obszar dociekań analityczno-badawczych nieznajdujący wyjaśnienia w tradycyjnych podręcznikach do teorii polityki. W tym sensie zjawisko kompleksowości - rozpoznane także w naukach przyrodniczych, społecznych, jak też fizykalnych - jest źródłem zaawansowanych studiów teoretycznych w kontekście funkcjonowania bądź organizowania się wspólnot politycznych, w tym zupełnie nowych form wpływu, dominacji, uzależnienia, rozproszenia itd. o charakterze politycznym ${ }^{9}$. Innym przykładem takiego ujęcia analityczno-badawczego jest transdyscyplinowa strategia badania cywilizacji światowej oparta na koncepcji wyjaśnienia integralnego, gdzie naukowy opis i eksplanacja dokonują się przez scalanie różnorodnych mechanizmów oraz czynników trwania/zmiany procesu historycznego w skali globu (Klementewicz, 2013, s. 35-120).

Na temat kompleksowości w naukach społecznych m.in.: Mainzer, 2007; Eve, Horsfall, Lee, 1997; Richards, 2000; Miller, Page, 2007; Sawyer, 2005. 
Nie mniej ważnym elementem twórczego teoretyzowania są wypowiedzi naukowców, w których powtarza się pogląd o ścisłej zależności między dokonaniem przełomowego odkrycia a podmiotowym olśnieniem (illumination). Z reguły taki stan psychiczny poprzedza stadium inkubacji, kiedy to praca umysłu badacza nie jest w pełni świadoma (płaszczyzna podświadomości). W tym sensie praca twórcza okazuje się wynikiem kombinacji różnych koncepcji (pomysłów), z których większość pozbawiona jest znaczenia w kontekście rozwiązania konkretnego problemu. Na tym etapie trudno określić poziom wrażliwości, empatii czy responsywności uczonego, gdzie stopniowalne pragnienie wynalezienia staje się niezbędnym składnikiem procesu odkrywania ${ }^{10}$. Przy tym twórcze myślenie w nauce - nazywane zdolnością wytwarzania dywergencyjnego - utożsamia się z mechanizmem rozwiązywania problemów badawczych. Z psychologicznego punktu widzenia zbieżność między twórczym myśleniem a poszukiwaniem rozwiązań problemu uwidocznia się w podobieństwie przebiegu tychże procesów w umyśle człowieka, gdzie można mówić o czterech fazach myślenia twórczego:

1. Preparacja - zbieranie informacji (myślenie twórcze wymaga oparcia się na określonych informacjach/danych. To warunek konieczny, ale niewystarczający).

2. Inkubacja - nieuświadomiona praca umysłu (nieświadome rozwiązywanie problemów bądź twórcze myślenie). Przy czym można mówić o dużych różnicach indywidualnych odnośnie do okresu inkubacji i jego przebiegu.

3. Olśnienie - pojawienie się „zainspirowanych” rozwiązań (nagły postęp w procesach myślowych, który przybiera postać intuicyjnych pomysłów, mających różny stopień jasności i kompletności). Przy czym „skok intuicyjny" nie jest związany z żadnym wysiłkiem, lecz niekiedy jest jądrem możliwej struktury myślowej. Taka intuicja / takie intuicje potrafią być myślą kluczową dla całościowego dylematu czy innowacji.

4. Weryfikacja - sprawdzanie i opracowywanie rozwiązań (ocena danych rozwiązań pod różnymi kątami i według różnorodnych kryteriów przez określone środowiska eksperckie). W pracy naukowej to ocena i krytyka określonych koncepcji, pomysłów, teorii, modeli itd. ze względu na ich użyteczność, spójność logiczno-semantyczną, prawdziwość, moc eksplanacyjną, funkcję predyktywną itd. (Guilford, 1978, s. 278-334, 595-630).

10 W tym względzie wysunięto dwie hipotezy odnośnie do wyjaśnienia mechanizmu olśnienia w praktyce naukowej: 1. hipotezę odpoczynku (przełom w myśleniu następuje tylko wtedy, gdy umysł jest wypoczęty i zrelaksowany); 2 . hipotezę zapominania (przełom w nauce może nastąpić tylko wtedy, gdy badacz „uwolni się” od krępujących założeń, schematycznego myślenia, obowiązujących paradygmatów itd., co oznacza podejście do problemu z „otwartą głową"). Zob. Hadamard, 1964, s. 31-47. 
Z kolei w odtwórczym teoretyzowaniu mentalne „zawieszenie” jest o wiele słabsze, gdyż oznacza ograniczenie się do tworzenia wyobrażeń obiektów (przedmiotów badań) wcześniej spostrzeganych i dobrze znanych danej społeczności uczonych. Przekładając to na język praktyki badawczej, mowa o próbie nowego spojrzenia, wypracowania odmiennej konceptualizacji czy interpretacji wobec wcześniej zdiagnozowanych, opisanych oraz wyjaśnionych - w postaci skodyfikowanych i spójnych systemów sądów o rzeczywistości - fenomenów politycznych. W tym układzie teoretyk odnosi się do pojęć, kategorii, procesów, stanów rzeczy, które w przeszłości były poddane analizie i zakończyły się sformułowaniem założeń teoretycznych. Element twórczości polega tutaj na próbie rekonceptualizacji obowiązujących teorii na gruncie nauki o polityce, $\mathrm{w}$ tym najczęściej na stopniowalnym zanegowaniu istniejących schematów postrzegania, definiowania czy wyjaśniania danych fragmentów świata polityki. To próba budowania innych teoretycznych rozwiązań, odmiennych od dominujących teorii antykumulatywnego charakteru wiedzy. Identyfikując konkretne deficyty deskryptywne czy eksplanacyjne ugruntowanych systemów i/lub szkół teoretycznych, próbuje się wypracować oraz skodyfikować nową teorię. W tym ujęciu wiedza naukowa ma charakter czasowy, odwoływalny oraz konwencjonalny. Oznacza to, że praca twórcza oparta na uruchamianiu odtwórczej wyobraźni umożliwia dokonywanie korekt w obowiązującym systemie teoretycznym, wykrywanie rzeczowych błędów, logicznych niespójności oraz nietrafnych diagnoz/prognoz wysuwanych przez poprzedników.

Przykładem tego typu zabiegów teoriopoznawczych na gruncie nauki o polityce jest chociażby wielonurtowy feminizm, który dokonuje rekonceptualizacji pojęcia polityczności. W tym rozumieniu podważa się tradycyjne definicje polityki (Jabłoński, 2012, s. 11-42) na rzecz wypracowania nowej teorii polityczności, która związana jest bezpośrednio z feministycznym paradygmatem badań nad społeczeństwem i polityką (Pierzchalski, 2013b, s. 239-253; Marsh, Stocker, 2006, s. 117-122). W tym rozumieniu jakościowo nowe teoretyzowanie wśród badaczy i badaczek o proweniencji feministycznej jest synonimem uruchamiania odtwórczych procesów wyobrażeniowych, gdzie przez myślowe reprezentacje (współtworzące nowe ramy pojęciowe i interpretacyjne) dokonuje się szczegółowych analiz politologicznych na temat typowych, historycznie ugruntowanych zjawisk oraz procesów determinujących mechanizmy władzy, stosunki polityczne czy szerzej - przestrzeń publiczną.

Omówione przypadki mentalnego „zawieszenia” są wyrazem kreatywnego rzemiosła uczonych, gdzie - używając argumentów Charlesa Wrighta Millsa mamy do czynienia $\mathrm{z}$ logiką kombinacji podczas pracy naukowej. To podmiotowa umiejętność zmieniania jednej perspektywy analityczno-badawczej na inną przy zachowaniu naukowego rygoru ścisłości, adekwatności czy spójności. Dla 
teoretyków polityki oznacza to intelektualną pracę, w której funkcjonują m.in. takie mechanizmy, jak:

1. Reorganizowanie katalogu - to warsztatowe zmienianie bądź porządkowanie na nowo problemów, zagadnień, paradoksów, kwestii spornych, antynomii itp. występujących $\mathrm{w}$ teorii polityki. To metoda, dzięki której teoretyk może uruchomić wyobraźnię - zwłaszcza nowatorskie asocjacje, metafory, pomysły - by w oryginalny sposób opisać, przedstawić bądź wyjaśnić wybrane kategorie, zagadnienia czy problemy współtworzące obowiązującą wiedzę politologiczną (przykładem tego typu mechanizmu na gruncie polskiej politologii jest eksplikacja pojęcia "politologiczna tradycja badawcza” na tle neofunkcjonalnego modelu wielowymiarowej wiedzy społecznej) (Nocoń, 2010, s. 81-129).

2. Słowotwórstwo - to postawa gotowości na swobodną zabawę słowami (zdaniami), przy pomocy których definiowane są różne problemy czy wyzwania teoretyczne. To strategia teoretyczno-badawcza mająca na celu wprowadzenie do obowiązującego słownika politologii neologizmów, które stają się synonimem semiotycznej kreatywności i/lub lingwistycznej wyobraźni twórczej (przykładem takich twórczych zabiegów językowych może być łączenie fenomenu rzeczywistości wirtualnej [cyberspace] z tradycyjną kategorią władzy politycznej [power], gdzie próbuje się naukowo badać nowe zjawisko cyberwładzy [cyberpower]) (Jordan, 1999).

3. Tworzenie nowych klasyfikacji - to koncepcyjne budowanie nowych typologii w obrębie teorii polityki, co jednocześnie sprzyja uaktywnianiu się wyobraźni danego badacza, jak również rozbudowuje daną siatkę pojęciową czy kategorialną w nauce o polityce (przykładem takiej pracy intelektualnej są chociażby prace teoretyczno-typologiczne odnośnie do fenomenu dyskredytacji politycznej bądź wrogości politycznej) (Karwat, 2007; Ziółkowski, 2013).

4. Analiza przypadków skrajnych - to myślenie i skrupulatne analizowanie przeciwieństw w stosunku do właściwego przedmiotu badania. Innymi słowy, gdy badacz myśli o miłości, to zastanawia się również nad nienawiścią; jeśli teoretyzuje o zjawisku interesowności w polityce, to dokonuje refleksji nad ideą bezinteresowności. W tym wariancie główna strategia naukowo-badawcza sprowadza się do konstruowania "typów biegunowych" i/lub antynomicznych typów idealnych, tj. opozycyjnych względem siebie w najróżniejszych wymiarach (przykładem tego typu zabiegów teoriopolitycznych może być praca na temat totalitaryzmu [Bäcker, 1992]) (Mills, 2007, s. 301-365).

Nie można jednak zapominać, że zarówno twórcza, jak i odtwórcza praca wyobraźni podczas powstawania teorii na gruncie nauki o polityce, żeby zosta- 
ła w intersubiektywny sposób uznana za naukową, musi podlegać naukowemu uzasadnianiu, co w gruncie rzeczy sprowadza się do wyznaczania ścisłych kryteriów, dzięki którym można dokonać selekcji i rozróżnienia między wiedzą naukową a potoczną refleksją na temat polityki (w naukoznawstwie wymienia się różne kryteria, np. prawdziwości, adekwatności, spójności semantyczno-syntaktycznej, poprawności logicznej wnioskowania itd.). W tym miejscu powraca problem opisany chociażby przez Karla R. Poppera, który stwierdził, że wyobraźnia twórcza jest nieodłącznym elementem procesu badawczego, lecz jednocześnie funkcjonuje w sposób niepodległy prawom logiki, co - niestety - w jakiejś mierze wykluczą ją z pola działalności naukowej. Stąd wyobraźnia twórcza staje się irracjonalną wyspą na oceanie racjonalnych działań naukowych, gdzie oba obszary się wzajemnie wykluczają i są zarazem od siebie zależne.

Praca naukowca polega na formułowaniu i sprawdzaniu teorii. Wydaje się, że studium początkowe, akt powzięcia pomysłu czy wymyślenia teorii, ani nie wymaga analizy logicznej, ani takiej analizie się nie poddaje. Pytanie, jak się to dzieje, że ktoś wpada na nowy pomysł - czy będzie nim temat muzyczny, intryga dramatyczna, czy teoria naukowa - może być niezmiernie interesujące dla psychologii empirycznej, jest jednak bez znaczenia dla logicznej analizy wiedzy naukowej (Popper, 1977, s. 32; Sady, 2013, s. 174-179).

Innymi słowy, wyobraźnia jest warunkiem koniecznym twórczej pracy badawczej w nauce o polityce - $\mathrm{w}$ tym jakościowo nowego, błyskotliwego teoretyzowania - lecz warunkiem niewystarczającym. Żeby mówić o prawdziwym naukowym orzekaniu i/lub wysuwaniu teoretycznych sądów o materii polityki, należy przyjąć odpowiednie kryteria uzasadniania tychże wypowiedzi czy konceptualizacji. We współczesnej nauce o polityce w zasadzie owe kryteria nie są stałe czy obiektywne, lecz podlegają ciągłej dyskusji wśród kompetentnych teoretyków. Konsekwencje tychże polemik uwidoczniają się m.in. w takich kwestiach, jak: wielokontekstowość definicji teorii, w tym wieloznaczność interpretacyjno-znaczeniowa odnośnie do pojęcia „teoria polityczna”; zróżnicowanie zakresowe i przedmiotowe teorii politologicznych; różnorodność wyznaczania obiektywnych kryteriów uznawalności danych sądów czy twierdzeń za teoretyczne; zrelatywizowana moc deskryptywna, eksplanacyjna czy predyktywna określonych teorii w obrębie nauki o polityce (Karwat, 2011, s. 75-93).

Reasumując, można stwierdzić, że wyobraźnia twórcza i odtwórcza to nieodłączne elementy każdej pracy intelektualno-badawczej. W pracy teoretycznej nie sposób pominąć formułowania się mentalnych procesów wyobrażeniowych, zwłaszcza że bezpośrednio zależą od mechanizmów introspekcyjnych oraz pośrednio warunkują efekty końcowe tejże pracy. W praktyce teoretyk(czka) 
analizujący(a) rzeczywistość polityczną - nawet jak nie jest w pełni świadomy(a) własnych ograniczeń i możliwości poznawczo-percepcyjnych - zawsze opiera się na myśleniu oraz na języku, co oznacza sprzężenie pośredniości z bezpośredniością postrzegania zmysłowego. Tylko w taki sposób można mówić o rzeczywistej organizacji, interpretacji oraz naukowej formalizacji określonych wrażeń zmysłowych, wynikających wprost ze złożonej i temporalnej relacji podmiot $\leftrightarrow$ przedmiot badania. Dlatego analiza fenomenu teoretyzowania czy formułowania teorii na gruncie nauki o polityce nie może pominąć psychologicznych aspektów pracy uczonych, gdzie generowanie oryginalnych pomysłów, twórcza ekspresja, podświadome olśnienia czy irracjonalne, wręcz fantasmagoryczne asocjacje w fazie konceptualizacji stają się ważnym - jeśli nie najważniejszym elementem badań teoretycznych. Bez tej płaszczyzny aktywności trudno w ogóle mówić o przełomowych poszukiwaniach czy prawdziwym rozwoju teoretycznym w obrębie nauki o polityce.

$\mathrm{Z}$ tego punktu widzenia dla osób aspirujących do bycia oryginalnymi teoretykami na gruncie nauki o polityce aktualna pozostaje reguła: im więcej prób mentalnego „zawieszenia” w politologicznej pracy teoriopoznawczej, tym większe szanse na twórczą aktywność teoretyczną. Innymi słowy, nie bójmy się uwalniać umysłów od zakorzenionych i wyuczonych schematów myślenia, postrzegania czy definiowania, a z całą pewnością nauka o polityce będzie dziedziną wiedzy $\mathrm{z}$ wieloma heurystycznymi teoriami naukowymi.

\section{Literatura}

Abraham, A., Windmann, S., Daum, I., Güntüurkün, O. (2005). "Conceptual Expansion and Creative Imagery as a Function of Psychoticism". Consciousness and Cognition, vol. 14.

Ajdukiewicz, K. (1985). „Zagadnienie uzasadniania”. W: K. Ajdukiewicz, Język i poznanie, t. 2. Warszawa: PWN.

Bäcker, R. (1992). Totalitaryzm. Geneza, istota, upadek. Toruń: Index Books.

Bermúdez, J.L. (2003). Thinking without Words. Oxford: Oxford University Press.

Bińczyk, E. (2012). Technonauka w społeczeństwie ryzyka. Filozofia wobec niepożadanych następstw praktycznego sukcesu nauki. Toruń: Wydawnictwo Naukowe UMK.

Cackowski, Z. (1979). „Ciągłość i nieciągłość ludzkiego poznania”. W: Z. Cackowski, J. Kmita (red.). Społeczny kontekst poznania. Wrocław: Zakład Narodowy im. Ossolińskich.

Carter, R. (2013). „Sprawstwo a to, co pozaludzkie”. W: A. Mrozowicki, O. Nowaczyk, I. Szlachcicowa (red.). Sprawstwo. Teorie, metody, badania empiryczne w naukach społecznych. Kraków: Zakład Wydawniczy Nomos. 
Dant, T. (2007). Kultura materialna w rzeczywistości społecznej. Wartości, działania, style życia, przeł. J. Barański. Kraków: Wydawnictwo Uniwersytetu Jagiellońskiego.

Eve, R.A., Horsfall, S., Lee, M.E. (eds.) (1997). Chaos, Complexity, and Sociology: Myths, Models, and Theories. London: Sage Publications.

Finke, R. (1990). Creative Imagery: Discoveries and Inventions in Visualization. Hillsdale, NJ: Lawrence Erlbaum Associates Inc.

Górniewicz, J. (1995). Szkice z teorii wyobraźni i samorealizacji. Toruń: PTP.

Guilford, J.P. (1978). Natura inteligencji człowieka, przeł. B. Czarniawska, W. Kozłowski, J. Radzick. Warszawa: PWN.

Gut, A. (2009). O relacji między myślą a językiem. Studium krytyczne stanowisk utożsamiających myśl z językiem. Lubin: Towarzystwo Naukowe KUL.

Hadamard, J. (1964). Psychologia odkryć matematycznych, przeł. R. Molski. Warszawa: PWN. Jabłoński, A.W. (2012). „Polityka. Teoretyczna ewolucja pojęcia”. W: A. Czajowski, L. Sobkowiak (red.). Polityka i polityczność. Problemy teoretyczne i metodologiczne. Wrocław: Wrocławskie Wydawnictwo Naukowe Atla 2.

Jordan, T. (1999). Cyberpower: An Introduction to the Politics of Cyberspace. LondonNew York: Routledge.

Karwat, M. (2007). O złośliwej dyskredytacji. Manipulowanie wizerunkiem przeciwnika. Warszawa: Wydawnictwo Naukowe PWN.

Karwat, M. (2011). „Rodzaje teorii w nauce o polityce”. W: Z. Blok (red.). Czym jest teoria $w$ politologii? Warszawa: Dom Wydawniczy Elipsa.

Klementewicz, T. (2004). „Teoria polityki w praktyce badawczej”. W: T. Klementewicz (red.). Współczesne teorie polityki - od logiki do retoryki. Studia Politologiczne, t. 8. Warszawa: Instytut Nauk Politycznych UW.

Klementewicz, T. (2013). Geopolityka trwałego rozwoju. Ewolucja cywilizacji i państwa $w$ trakcie dziejotwórczych kryzysów. Warszawa: Dom Wydawniczy Elipsa.

Kozielecki, J. (1968). Zagadnienia psychologii myślenia. Warszawa: PWN.

Krauz-Mozer, B. (2005). Teorie polityki. Założenia metodologiczne. Warszawa: Wydawnictwo Naukowe PWN.

Krauz-Mozer, B. (2013). „Metodologia jako forma samowiedzy badawczej”. W: Ł. Młyńczyk, B. Nitschke (red.). Aspekty metodologiczne oraz teoretyczne w subdyscyplinach politologii. Toruń: Wydawnictwo Adam Marszałek.

Limont, W. (1996). Analiza wybranych mechanizmów wyobraźni twórczej. Badania eksperymentalne. Torun: Wydawnictwo Uniwersytetu Mikołaja Kopernika.

Łukasik, A. (2008). Filogeneza i adaptacyjne funkcje ludzkiej wyobraźni. Rzeszów: Wydawnictwo Uniwersytetu Rzeszowskiego.

Mainzer, K. (2007). Poznanie złożoności. Obliczeniowa dynamika materii, umysłu i ludzkości. Lublin: Wydawnictwo UMCS.

Makota, J. (1988). „O wyobraźni twórczej”. W: K. Wilkoszewska (red.). Eseje o pięknie. Problemy estetyki i teorii sztuki. Warszawa-Kraków: PWN. 
Marsh, D., Stocker, G. (red.) (2006). Teorie i metody $w$ naukach politycznych, przeł. J. Tegnerowicz. Kraków: Wydawnictwo Uniwersytetu Jagiellońskiego.

Maruszewski, T. (1983). Analiza procesów poznawczych jednostki w świetle idealizacyjnej teorii nauki. Poznań: Wydawnictwo Naukowe UAM.

Maruszewski, T. (2011). Psychologia poznania. Umysł i świat. Gdańsk: Gdańskie Wydawnictwo Psychologiczne.

Miller, J.H., Page, S.E. (2007). Complex Adaptive Systems: An Introduction to Computational Models of Social Life. Princeton: Princeton University Press.

Mills, C.W. (2007). Wyobraźnia socjologiczna, przeł. M. Bucholc. Warszawa: Wydawnictwo Naukowe PWN.

Morton, A. (2002). Przewodnik po teorii poznania, przeł. T. Baszniak. Warszawa: Wydawnictwo Spacja.

Nagel, T. (1997). Widok znikąd, przeł. C. Cieśliński. Warszawa: Fundacja Aletheia.

Nęcka, E., Orzechowski, J., Szymura, B. (2013). Psychologia poznawcza. Warszawa: Wydawnictwo Naukowe PWN.

Nocoń, J. (2010). Między tradycja a modernizacją. Przeobrażenia badań politologicznych $w$ świetle neofunkcjonalizmu Jeffreya C. Alexandra. Bydgoszcz: Wydawnictwo Uniwersytetu Kazimierza Wielkiego.

Nowak, S. (2007). Metodologia badań społecznych. Warszawa: Wydawnictwo Naukowe PWN.

Pierzchalski, F. (2013a). „Dynamika układów pojęciowych w nauce o polityce”. W: Ł. Młyńczyk, B. Nitschke (red.). Aspekty metodologiczne oraz teoretyczne w subdyscyplinach politologii. Toruń: Wydawnictwo Adam Marszałek.

Pierzchalski, F. (2013b). „Polityka jako «męskie spojrzenie»”. W: B. Kaczmarek (red.). Metafory polityki, t. 4. Warszawa: Dom Wydawniczy Elipsa.

Pierzchalski, F. (2014). „Bezbłędna niezgoda - o rozbieżnościach analityczno-badawczych w nauce o polityce”. W: P. Borowiec, R. Kłosowicz, P. Ścigaj (red.). Odmiany współczesnej nauki o polityce, t. 1. Kraków: Wydawnictwo Uniwersytetu Jagiellońskiego.

Pieter, J. (1971). Psychologia nauki. Warszawa: Wiedza Powszechna.

Poczobut, R. (2009). Między redukcją a emergencją. Spór o miejsce umystu w świecie fizycznym. Wrocław: Wydawnictwo Uniwersytetu Wrocławskiego.

Popper, K.R. (1977). Logika odkrycia naukowego, przeł. U. Niklas. Warszawa: PWN.

Przełęcki, M. (1966). „Pojęcia teoretyczne a doświadczenie”. W: T. Pawłowski (red.). Logiczna teoria nauki. Warszawa: PWN.

Richards, D. (2000). Political Complexity: Nonlinear Models of Politics. Ann Arbor: The University of Michigan Press.

Sady, W. (2013). Spór o racjonalność naukową. Od Poincarégo do Laudana. Toruń: Wydawnictwo Naukowe Uniwersytetu Mikołaja Kopernika.

Sawyer, R.K. (2005). Social Emergence: Societies as Complex Systems. Cambridge: Cambridge University Press. 
Such, J. (1975). Problem weryfikacji wiedzy. Studium metodologiczne. Warszawa: PWN.

Ward, T.B. (1994). "Structured Imagination: The Role of Conceptual Structure in Exemplar Generation". Cognitive Psychology, vol. 27, no. 1.

Ziółkowski, J. (2013). Wrogość w stosunkach politycznych. Modelowa analiza funkcjonalna. Warszawa: Dom Wydawniczy Elipsa.

Żuk, T. (1986). Uzdolnienie twórcze a osobowość. Poznań: Wydawnictwo Naukowe UAM. Żukrowska, A. (2002). Powrót do źródeł wiedzy. W sprawie tradycji filozoficznej kognitywistyki. Warszawa: Wydawnictwo Naukowe Scholar.

\section{Streszczenie}

Celem artykułu jest analiza wyobraźni twórczej jako źródła tworzenia teorii i teoretyzowania na gruncie nauki o polityce. W tym rozumieniu dokonano trójstopniowej odsłony głównych wątków refleksji metodologicznej, które są synonimem mechanizmu tworzenia teorii w politologii. Odsłona przebiega według następującego schematu: wyobraźnia ludzka $\rightarrow$ pośredniość poznania $\rightarrow$ twórcze teoretyzowanie.

Słowa kluczowe: wyobraźnia twórcza, olśnienie, twórcze teoretyzowanie, pośredniość/bezpośredniość naukowego poznania, myślenie dywergencyjne 